\title{
The Sustainable Development Goals and Technological Capacity*
}

\author{
David Mayer-Foulkes ${ }^{1}$, Edson Serván-Mori², and Gustavo Nigenda ${ }^{3}$
}

Suggested citation Mayer-Foulker D, Serván-Mori E, Nigenda G. The Sustainable Development Goals and Technological Capacity. Rev Panam Salud Publica. 2021;45:e81. https://doi.org/10.26633/RPSP.2021.81

SUMMARY

In order to achieve the Sustainable Development and Health Goals, it is essential to increase the technological capacity of the most disadvantaged populations. In the 21st century, the necessary technologies for this exist. The gap in technological capacity reflects the existence of a technological gradient between large- and smallscale production, due to an absence of incentives for innovation and a lack of technological dissemination in small businesses and communities. Technological change is central to development, but it is a public good that the market economy does not provide efficiently. Providing it requires the implementation of public policies aimed at technological innovation and dissemination. Reducing the technological gradient is therefore a major part of the United Nations 2030 Agenda for Sustainable Development and the Pan American Health Organization's 2018-2030 Sustainable Health Agenda for the Americas. This also applies to the development of health systems, which function as a redistribution mechanism to break poverty traps. In addition, experiences in these systems are relevant to the implementation of policies that increase technological capacities aimed at reducing poverty, improving social determinants of health, and thereby reducing the scale of the human development trap.

Keywords

Science, technology and society; sustainable development; equity; health systems; health policy; social determinants of health.

The Sustainable Development Goals (SDGs), established in the United Nations 2030 Agenda for Sustainable Development (1), and the Sustainable Health Agenda for the Americas 20182030, promulgated by the Pan American Health Organization (PAHO) (2), aim to reduce poverty, promote industrialization and sustainable development, and attain the highest attainable standard of health and equity. These multisectoral objectives are integrated and indivisible, being mutually dependent on each other, as outlined in the social determinants of health $(\mathrm{SDH})$ framework $(3,4)$.

\footnotetext{
* Official English translation from the original Spanish manuscript made by the Pan American Health Organization. In case of discrepancy, the original version shall prevail. Access to original manuscript: https://doi.org/10.26633/ RPSP.2020.141

1 Center for Research and Teaching in Economics, Mexico. $\square$ David MayerFoulkes, david.mayer@cide.edu

2 Center for Health Systems Research. National Institute of Public Health, Mexico.
}

The distribution of economic and human development, including real wages, directly reflects differences in technological levels, ${ }^{4}$ both between and within countries. Achieving technological development with equity is a necessary condition both for sustaining access to sufficiently productive paid work, and for achieving the SDGs. This article shows how technological development, particularly in small-scale production in the low-income population, is by nature a public good that is inefficiently provided by the market; hence its close connection to the SDGs.

\footnotetext{
3 National School of Nursing and Obstetrics of Mexico. National Autonomous University of Mexico, Mexico.

4 Technology is understood as procedures used to turn inputs into outputs (not only in information technology). Technological development is the advance in these production techniques.
} 
Following Sen and Nussbaum's capability approach, capabilities should extend from the individual to the societal level. For example, exercising the right to work by itself is not enough because the work must be sufficiently productive-a societal attribute, not just an individual or private one. That is to say that technological capabilities are societal attributes. The same is the case for education and health, whose markets and distribution also operate with failures.

In modern industrial societies, large companies with largescale production yield more technological change than small enterprises, and the technology of large companies advances with greater momentum than that of small enterprises. Consequently, a technological gradient-i.e., differences in productivity-is generated between large- and small-scale sectors $(5,6)$. A relative lag emerges in the productivity of smaller-scale enterprises, which employ a significant portion of the population. This unequal distribution of productivity is directly related to unequal income distribution. The association between income inequality and life expectancy has already been demonstrated (7).

The following figures illustrate the technological and wage gradient characteristic of industrial economies. In Mexico in 2013, average annual remuneration in microenterprises with ten employees or fewer-which employed $20.8 \%$ of workers-was MXN 53 500, while in enterprises with more than 251 employees-which employed $53.6 \%$ of workers-it was MXN 169500 , or 3.17 times more (8). In the United States of America in 2017, manufacturing companies with production of less than US\$100 million-with 19.1 employees on average and employing $39.4 \%$ of workers-paid an average wage of US $\$ 47397$, while those with production greater than US\$2.5 billion-with 5657.4 employees on average and employing $30.8 \%$ of workers-paid US\$71 666; i.e., 1.51 times more (9). As can be seen, wage inequality was proportionally greater in Mexico than in the United States.

The following section analyzes the nature of technological development as a public good and explains how the technological gradient is generated. It points out the basic dynamic role of the technological gradient in the SDHs, exemplified by the human development trap ${ }^{5}$, and explains how its magnitude is related to the technological gradient and the deficit in technological capabilities. Finally, it analyzes the mutual impact between policies for health systems management and those for building technological capabilities.

\section{THE GRADIENT IN TECHNOLOGICAL CAPABILITIES}

Change in any type of production technique, i.e., technological change, consists mainly of creating knowledge. Because knowledge is a public good, investing in creating it is profitable only if its benefit can be appropriated. In large enterprises this appropriation is more feasible-sometimes facilitated by patents-and the magnitude of the benefit justifies greater investment. In small enterprises, on the other hand, innovations are more likely to become known or disseminated, which reduces the appropriable benefit, and the investment may not be justified. However, the creation of such a public good could be justified for the productive sector as a whole. While investment

In a poverty trap, families belong to different levels of higher or lower equilibrium, where market dynamics cannot diminish the differences. in technological change may be suboptimal even in large-scale sectors, in small-scale sectors it may remain simply as a potential public good if there are no incentives to bring it to fruition. In these sectors, technological change does not take place and it remains limited to the purchase of innovative inputs produced in large enterprises or to new knowledge from skilled personnel.

In short, innovation in large-scale sectors is more intense than in small-scale sectors because in small enterprise and community settings, the market economy does not provide sufficient incentives for technological innovation and diffusion. This dynamic generates a technological gradient, both in research and development and in technological diffusion. Technological differences arise due to different rates of innovation in sectors of different scales. This argument has been previously formalized $(5,6)$. The magnitude of the technological gradient varies among areas and countries and is more pronounced where inequality is greater.

Large enterprises can finance their own technological developments by employing skilled personnel, scientific research, and other forms of social collaboration. In the case of small enterprises, this collaboration is even more necessary. Education and science can create and disseminate technology. The productive, educational, and scientific sectors should be linked to the entire productive and technological spectrum, both small- and large-scale. In their education, students in various fields can be involved in a curriculum of meaningful activities in productive and health sectors, which can be incorporated into their training and future employment opportunities. Program content and teaching, as well as the technologies used by small-, medium-, and large-scale producers, can be improved in this process at practically no additional cost by integrating appropriate criteria into the implementation of existing activities. Innovation can also be encouraged to benefit the least favored sectors, both in the production of goods and services to meet basic needs-including housing, food, health, water, sewerage, and sustainability-and in their various fields of work. The great diversity of technologies currently available can be applied to solve problems of all kinds.

Successfully strengthening technological capabilities-which depends on public action-reduces poverty and increases opportunities for a healthy life. Increased income among lower-income economic sectors, achieved by improving their productive fundamentals, will induce a multiplier effect that will make all sectors grow, generating momentum for integrated development with positive effects on attainment of the SDGs.

\section{TECHNOLOGICAL GRADIENT AND SOCIAL DETERMINANTS OF HEALTH}

The elements described above suggest that technological development constitutes the dynamic backdrop to the determinants of the health-disease process, fundamental to the identification, design, and implementation of effective longterm social welfare strategies.

A smaller technological gradient promotes positive outcomes in health and well-being, increases access to basic goods and primary health care services, and mitigates health inequities, generating political and cultural development and institutional maturity. Technological development influences health through the social structures of opportunity and access to resources, and as a mechanism for redistributing advances in health. 
Various fields of knowledge have analyzed the healthdisease process and its complex relationships with determinants, whether from a biological view of the process, as in the biomedical sciences, or from a socio-ecological standpoint, which considers the non-biological factors that explain health-related disparities (10). However, none of them consider technological distribution and its dynamics; nor do current health policies $(11,12)$.

The dynamic technology-health link expands the SDH framework (13) by determining that the conditions in which people are born, live, work, age, and die express their technological capabilities, which in turn depend on social organization and positioning $(3,4)$. The SDHs comprise all the social characteristics that affect health (13). Disadvantaged population groups experience poorer health due to social inequality and differential access to basic resources, and of population-level capabilities such as schooling and unemployment, among others, which together define their technological capabilities at the societal level. The importance of the SDHs has been widely recognized $(13,14)$.

Figure 1 is an adaptation of the conceptual framework of the World Health Organization's Commission on Social Determinants of Health based on Solar and Irwin's (3) framework, which includes the technological component, in both a static and a dynamic sense. Statically, technology is considered part of the structural determinants (economic, political, cultural, and social) and, in turn, the technological gradient shapes the intermediate and proximal determinants. Dynamically, technological change - and its distribution-is a fundamental factor in structural and intermediate determinants. Reducing the technological gradient and thereby increasing technological capabilities is essential for reducing inequity in the SDHs. The health system is among the intermediate determinants, since it conditions distribution of opportunities for access to health services and the quality with which services are provided, with implications for financial vulnerability, particularly in impoverished populations. Ultimately, the technological gradient shapes the way in which people, the health system, and information interact, and the relative lags in these interactions. Maximizing the effect of technological developments on population health will closely depend on sustainable and equitable implementation, based on principles of local collaboration and in accordance with ethical principles and values.

\section{HUMAN DEVELOPMENT AND THE TECHNOLOGICAL GRADIENT}

The dynamic role of the technological gradient in the SDHs can be addressed through human development. This requires investments in childhood and youth-e.g., in education and health-which parents with low human development levels often cannot make, although they are necessary. Consequently, inequalities or the gradient in human development tend to be transmitted from one generation to the next (15). This situation constitutes a market failure that creates a poverty trap that, in turn, perpetuates an unfair distribution of human development throughout the societal structure. When this trap subsists in a context of technological development it is called a human development trap $(16,17)$.

The figure shows the distribution of human development over time, modeled as the result of a dynamic poverty trap in a context of technological change differentiated by socioeconomic levels. The poverty trap is due to intergenerational market and institutional failures. The vertical axis shows a stratified population: the poorest live at a lower technological

FIGURE 1. Technology as a social determinant of health

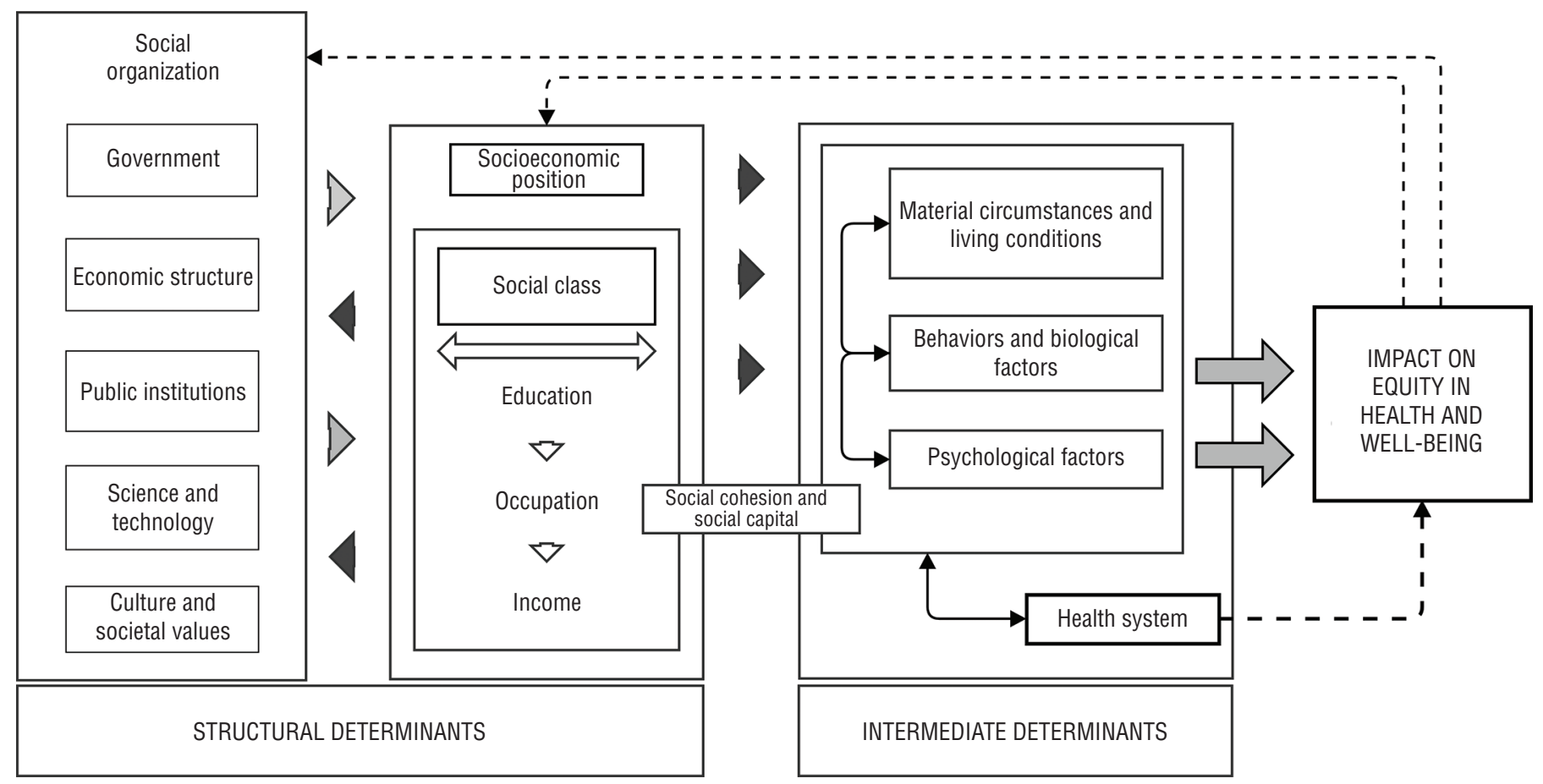

Source: Prepared by the authors, based on information from Reference 3. 


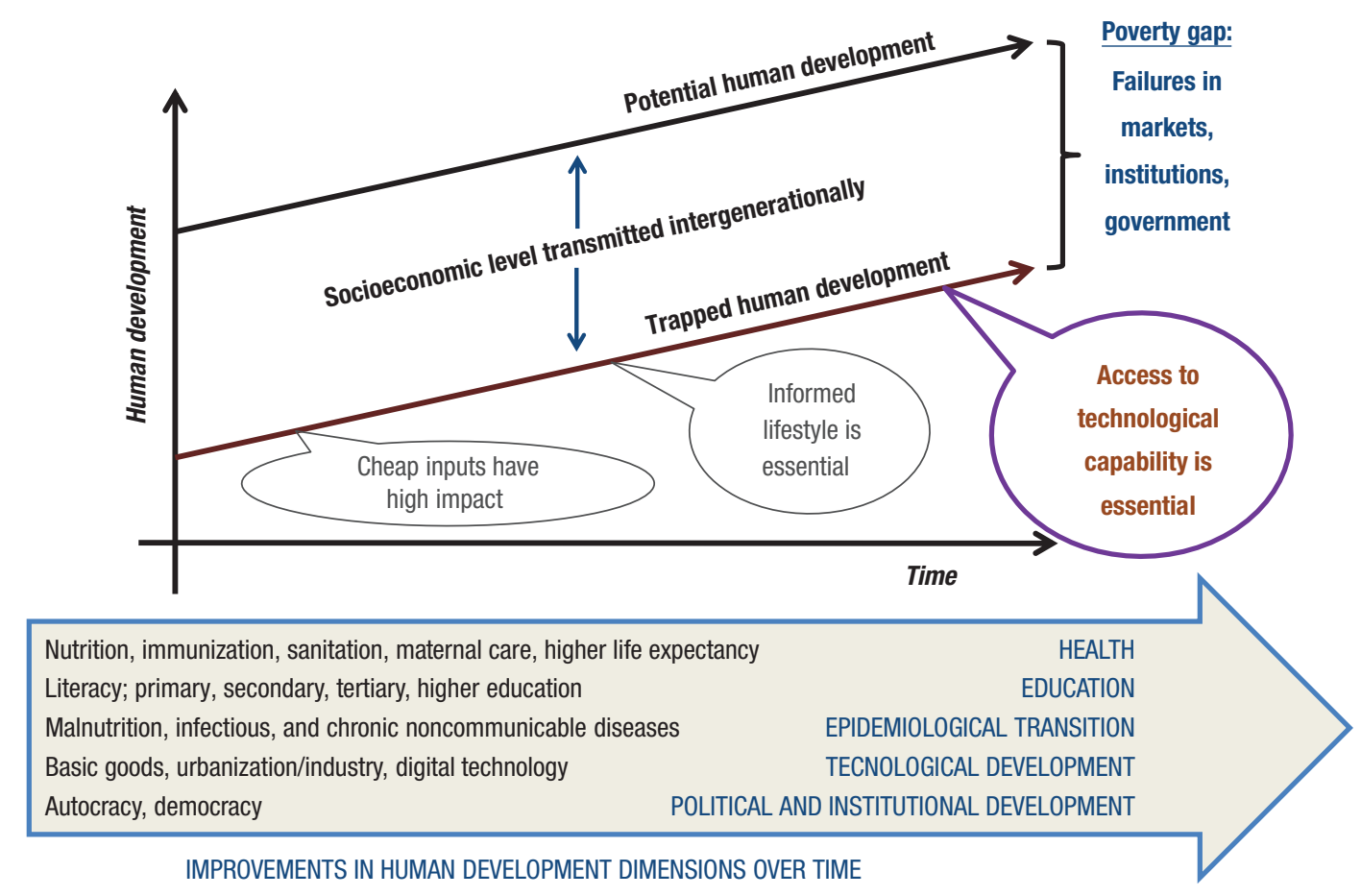

Source: Prepared by the authors, based on Mayer-Foulkes and Pescetto-Villouta (17), with authorization from Walter de Gruyter GmbH, through the Copyright Clearance Center, Inc.

level and fail to endow their children with sufficient human capital to attain their society's potential human development levels. Although technological and human development levels increase over time, significant lags remain. The vertical depth of the human development trap is a function of the technological gradient. The horizontal axis shows the epidemiological transition from communicable and nutritional diseases to chronic noncommunicable diseases. There is a transition from relatively simple and straightforward technologies, such as vaccines and sanitation, to the provision and distribution of other technologies, such as a healthy diet and healthy lifestyles, which involve both collective and individual aspects. The next stage requires access to sustainable technological capabilities.

Figure 2 shows that the trap (17) includes, among other elements, epidemiological transition involving a change in the pattern of mortality and morbidity from communicable and nutritional diseases to chronic noncommunicable diseases. The 21st century is bringing the next transition, in which technological capabilities are the main health determinants, particularly in middle- and low-income countries. In all basic categories-housing, food, health, medicine, education, and work-technology is sufficiently advanced for the population as a whole to enjoy high levels of health and well-being. Thus, the increase in population health and well-being increasingly depends on technological capabilities. The importance of inequality in these capabilities, including access to productive work-i.e., the technological gradient-is becoming increasingly evident.

In short, the depth of the human development trap and lags in the SDGs are a result of the magnitude of the technological gradient.

\section{HEALTH SYSTEMS: TECHNOLOGY AND IMPLICATIONS OF PUBLIC POLICIES}

How can we integrate health systems management and public policies that promote the SDGs? The core issue is to achieve effectiveness and feedback in the multisectoral integration of such policies.

The health system is part of the technological system, and the rationality of its design and operation improves with the technical capability of its operators and the populations it covers (18). It is essential to reduce the technological gradient effectively, both within health systems and in its societal context. Addressing the epidemiological transition requires people to actively improve their health by adopting healthy lifestyles (19). Attaining the SDGs requires the health sector to promote the technological capabilities of the population to provide for its health and well-being.

Public financing of health systems enables health-related achievements and facilitates impact on the SDHs, in coordination with local and national public policies. This may also include the capability to make the appropriate assessments at local and national levels. Public financing can allocate resources to populations based on local technological conditions, which contributes to reducing poverty traps. Equity and cost-effectiveness criteria can be applied across the board with the inclusion of specific objectives to distribute technology to reduce the technological gradient, possibly through targeted public subsidies (20).

An important technological component for the contextualized operation of health systems is reliable, relevant, and timely information systems (21). These make it possible to monitor the conditions of health and well-being in populations and identify gaps in care. Information systems are key for strategic 
and situational planning and they constitute an integrated extension of technological capabilities. In the current COVID19 pandemic, the administration of population screening tests provides an example of how a technology can expand management capabilities.

\section{FINAL CONSIDERATIONS}

Achieving sustainable development and health goals is inseparable from technological development and increased technological capabilities for the most disadvantaged population groups. This is lagging because in small-scale sectors, technological innovation and distribution have the characteristics of a public good and are not envisioned efficiently for the market, causing them to fall behind on the technological gradient. The history of public health policies contains a unique institutional legacy of creating public goods and upholding egalitarian ethical values. This provides a starting point and support for public policies that reduce the technological gradient, thereby reducing inequality through the use of objective and efficient methodologies and criteria to promote the health and well-being of the entire population.

Authors' contributions. All the authors conceived the original study, wrote the manuscript, and reviewed and approved the final version.

\section{Conflict of interests. None declared.}

Disclaimer. Authors hold sole responsibility for the views expressed in the manuscript, which may not necessarily reflect the opinion or policy of the RPSP/PAJPH and/or PAHO.

\section{REFERENCES}

1. United Nations General Assembly. Transforming our World: the 2030 Agenda for Sustainable Development (A/ RES/70/1). New York: UN; 2015 [accessed 19 August 2020]. Available at: https:// www.un.org/en/development/desa/population/migration/gen eralassembly/docs/globalcompact/A_RES_70_1_E.pdf

2. Pan American Health Organization, World Health Organization. The Sustainable Health Agenda for the Americas 2018-2030: A call to action for health and well-being in the region [Internet]. Washington, DC: PAHO, WHO; 2017 [accessed 2 August 2020]. Available at: https:/ /iris.paho.org/bitstream/handle/10665.2/49170/CSP296eng.pdf? sequence $=1$ \&is Allowed $=y$

3. Solar O, Irwin A. A conceptual framework for action on the social determinants of health. Geneva: World Health Organization; 2010. (Series on Social Determinants of Health Report No. 2).

4. Palmer RC, Ismond D, Rodríguez EJ, Kaufman JS. Social determinants of health: future directions for health disparities research. Am J Public Health. 2019;109(S1):S70-1.

5. Mayer-Foulkes D. Macroeconomics of poverty: Development and underdevelopment under globalization. Scotts Valley, CA: First Create Space Independent Publishing Platform; 2017.

6. Benhabib J, Perla J, Tonetti C. Reconciling models of diffusion and innovation: A theory of the productivity distribution and technology frontier. Cambridge, MA: National Bureau of Economic Research; 2017. (NBER Working Papers).

7. Hertog S. The association between two measures of inequality in human development: income and life expectancy. New York; United Nations; 2013 [accessed 2 August 2020]. (Technical Paper No. 2013/7). Available at: https://www.un.org/development/ $\mathrm{desa} / \mathrm{pd}$ / sites / www.un.org.development.desa.pd/files/files / documents/2020/Jan/un_2013_techpaper7.pdf

8. México, Instituto Nacional de Estadística, Geografía e Informática. Micro, pequeña, mediana y gran empresa. Estratificación de los establecimientos. Censos Económicos [Internet]. 2014 [accessed 6 August 2020]. Available at: http://internet.contenidos.inegi.org. $\mathrm{mx} /$ contenidos/productos//prod_serv/contenidos/espanol/bvi negi/productos/nueva_estruc/702825077952.pdf

9. United States Census Bureau. Number of Firms, Number of Establishments, Employment, and Annual Payroll by Enterprise Employment Size for the United States and States, Totals: 2017. 2020 [accessed 2 August 2020]. Available at: https:/ / www2.census.gov/ programs-surveys/susb/tables/2017/us_naicssector_large_rcpt size_2017.xlsx
10. Robert SA. Socioeconomic position and health: The independent contribution of community socioeconomic context. An Rev Sociol [Internet]. 1999;25(1):489-516 [accessed 2 August 2020]. Available at: http://www.annualreviews.org/doi/abs/10.1146/annurev.soc. 25.1.489? journalCode $=$ soc

11. Abramo L, Cecchini S, Ullmann H. Enfrentar las desigualdades en salud en América Latina: el rol de la protección social. Cien Saude Colet. 2020;25:1587-98.

12. Mújica ÓJ, Moreno CM. De la retórica a la acción: medir desigualdades en salud para no dejar a nadie atrás. Rev Panam Salud Publica. 2019;43:e12.

13. Marmot M, Friel S, Bell R, Houweling TAJ, Taylor S. Closing the gap in a generation: health equity through action on the social determinants of health. Lancet. 2008;372(9650):1661-9.

14. Graham H. Social determinants and their unequal distribution: Clarifying policy understandings. Milbank Q. 2004;82(1):101-24.

15. Case A, Lubotsky D, Paxson C. Economic status and health in childhood: The origins of the gradient. Am Econ Rev. 2002;92(5):1308-34.

16. Mayer-Foulkes D. The human development trap in Mexico. World Dev. 2008;36(5):775-96.

17. Mayer-Foulkes DA, Pescetto-Villouta C. Economic development and non-communicable chronic diseases. Glob Econ J. 2012;12(4):1-44.

18. Repullo Labrador JR, Segura Benedicto A. Salud pública y sostenibilidad de los sistemas públicos de salud. Rev Esp Salud Publica. 2006;80(5):475-82.

19. World Health Organization. From Alma-Ata to Astana: Primary health care-reflecting on the past, transforming for the future. Geneva: WHO; 2018.

20. World Bank. World Development Report 1993: Investing in Health. Washington, DC: WB; 1993.

21. Plazzotta F, Luna D, González Bernaldo de Quirós F. Sistemas de información en salud: integrando datos clínicos en diferentes escenarios y usuarios. Rev Peru Med Exp Salud Publica. 2015;32(2):343-51.

Manuscript (original in Spanish) received on 21 May 2020. Revised version accepted for publication on 17 October 2020. 


\section{Los Objetivos de Desarrollo Sostenible y las capacidades tecnológicas}

RESUMEN Para lograr los objetivos de desarrollo y salud sostenibles, es esencial incrementar las capacidades tecnológicas de las poblaciones más desfavorecidas. Entrado el siglo XXI, existen las tecnologías necesarias para ello. El déficit en capacidades tecnológicas se debe a la existencia de un gradiente tecnológico entre la producción de gran y de pequeña escalas, debido a la falta de incentivos para la innovación y la difusión en empresas y comunidades pequeñas. En estos ámbitos el cambio tecnológico, punto medular del desarrollo, es un bien público que la economía de mercado no provee eficientemente. Su provisión requiere la aplicación de políticas públicas de innovación y difusión tecnológicas. La reducción del gradiente tecnológico constituye, pues, parte medular de la Agenda 2030 para el Desarrollo Sostenible, de las Naciones Unidas, y la Agenda de Salud Sostenible para las Américas 2018-2030, de la Organización Panamericana de la Salud. Esto es aplicable, así mismo, al desarrollo de los sistemas de salud, que funcionan también como mecanismos de redistribución para romper las trampas de pobreza. Asimismo, las experiencias en esos sistemas tienen relevancia para aplicar políticas de incremento de capacidades tecnológicas que disminuyan la pobreza, mejoren los determinantes sociales de la salud y, con ello, reduzcan la magnitud de la trampa de desarrollo humano.

Palabras clave Ciencia, tecnología y sociedad; desarrollo sostenible; equidad; sistemas de salud; política de salud; determinantes sociales de la salud.

\section{Os Objetivos de Desenvolvimento Sustentável e a capacidade tecnológica}

RESUMO Para alcançar os objetivos de desenvolvimento e saúde sustentáveis, é fundamental aumentar a capacidade tecnológica das populações mais desfavorecidas. Com a entrada do século XXI, há tecnologias necessárias para isso. O déficit em capacidade tecnológica decorre de um gradiente tecnológico entre a produção em pequena e larga escala pela falta de incentivos à inovação e difusão em empresas e comunidades pequenas. Nestas esferas, a evolução tecnológica, que é o eixo do desenvolvimento, é um bem público que não é provido de forma eficiente pela economia de mercado. Políticas públicas de inovação e difusão tecnológicas são necessárias. Diminuir o gradiente tecnológico constitui, portanto, a base da Agenda 2030 para o Desenvolvimento Sustentável, da Agenda das Nações Unidas e da Agenda de Saúde Sustentável para as Américas 2018-2030 da Organização Pan-Americana da Saúde. Requer também o desenvolvimento dos sistemas de saúde que servem como mecanismos de redistribuição para romper com as armadilhas da pobreza. Ademais, a experiência adquirida nesses sistemas é indispensável para instituir políticas de aumento da capacidade tecnológica que diminuam a pobreza, melhorem os determinantes sociais da saúde e, assim, reduzam a dimensão da armadilha do desenvolvimento humano.

Palavras-chave Ciência, tecnologia e sociedade; desenvolvimento sustentável; equidade; sistemas de saúde; política de saúde; determinantes sociais da saúde. 